F. Reprod. Fertil. (1965) 10, 273-275

BRIEF COMMUNICATION

\title{
STRAIN DIFFERENCES IN SUSCEPTIBILITY OF MICE AND RATS TO CADMIUM-INDUCED TESTICULAR DAMAGE
}

\author{
SAMUEL A. GUNN, THELMA GLARK GOULD \\ AND W. A. D. ANDERSON \\ Department of Pathology, University of Miami School of Medicine, \\ Miami, Florida, U.S.A.
}

(Received 3rd May 1965)

The observations of Pařízek \& Zahor (1956) and Pařizek (1957a, b) on the selective destructive effect of cadmium on the testis of the rat and mouse have since been confirmed by Meek (1959), Kar \& Das (1960), Gunn, Gould \& Anderson (1961), Allanson \& Deanesly (1962), Chiquoine (1964), Mason, Brown, Young \& Nesbit (1964) and others. During studies on the induction of interstitial cell tumours of the testis by cadmium (Gunn, Gould \& Anderson, 1963), we noted that cadmium failed to cause any degree of damage to the testis of the BALB/c mouse. A study was, therefore, undertaken to determine if this resistance to cadmium-induced testicular injury was unique to the BALB/c strain of mice and whether strain differences in testicular response to cadmium might also be observed in rats. A single subcutaneous (interscapular) injection of $0.03 \mathrm{~m}$-mole $/ \mathrm{kg}$ of $\mathrm{CdCl}_{2}$ was chosen for the preliminary testing since overwhelming testicular destruction, without other manifestations of acute toxicity, had been reported with this approximate dosage in both rats and mice (Pařizek \& Zahor, 1956; Pařízek, 1957a, b; Meek, 1959; Kar \& Das, 1960; Gunn et al., 1961). Animals were killed $48 \mathrm{hr}$ after the injection of cadmium.

A total of 130 mature (8-week-old) male mice, composed of eighteen different inbred strains* and one random bred strain (CD-1, derived from $\mathrm{HaM} / \mathrm{ICR}$ Swiss mice) $\uparrow$ were tested. Following the administration of $\mathrm{CdCl}_{2}$, necrosis was seen consistently in the random-bred CD-1 strain, as well as in ten of the inbred strains: AKR/J, CBA/J, C57BR/cdJ, C57L/J, C58/J, DBA/1J, DBA/2J, $\mathrm{RF} / \mathrm{J}, \mathrm{SWR} / \mathrm{J}$ and $129 / \mathrm{J}$. The $\mathrm{SJL} / \mathrm{J}$ strain gave a variable response. Experiments with lower doses revealed that the amount of cadmium needed to produce minimal testicular damage varied within these susceptible strains.

Seven of the inbred strains of mice showed no microscopic evidence of testicular damage from $\mathrm{CdCl}_{2}: \mathrm{A} / \mathrm{HeJ}, \mathrm{A} / \mathrm{J}, \mathrm{BALB} / \mathrm{cJ}, \mathrm{C} 3 \mathrm{H} / \mathrm{HeJ}, \mathrm{C} 3 \mathrm{HeB} / \mathrm{FeJ}$, $\mathrm{C} 57 \mathrm{BL} / 6 \mathrm{~J}$ and $\mathrm{C} 57 \mathrm{BL} / 10 \mathrm{~J}$. Increasing the dose of cadmium to the lethal range still did not produce a testicular effect.

* The Jackson Laboratory, Bar Harbor, Maine.

† Charles River Mouse Farms, Inc., North Wilmington, Massachusetts. 
A total of ninety mature (12-week-old) male rats were tested, composed of Wistars from two commercial sources ( $\mathrm{W}^{*}$ and CFN $\dagger$ ), Sprague-Dawleys from two commercial sources (CFE $\dagger$ and $\mathrm{SD} \ddagger$ ), a strain descended from the SpragueDawley $\left(\mathrm{CD}^{*}\right)$ and an inbred Fischer strain $\left(\mathrm{CD}-\mathrm{F}^{*}\right)$. All of these rats showed characteristic testicular injury, but there were indications that the dose of cadmium needed to produce minimal testicular damage may differ in the various strains and even in the same strains of rats derived from different commercial sources. This may explain why low doses of $\mathrm{CdCl}_{2}$, which have been reported by others (Kar \& Das, 1960; Kar, Dasgupta \& Das, 1961; Mason et al., 1964) as sufficient to damage the rat testis, have been completely ineffective in our hands.

Although this particular communication deals only with the male rat and mouse, strain and even substrain differences in susceptibility may explain the apparently contradictory findings presented below on the effects of cadmium in various species. Paŕizek (1957b) and earlier Hessel (1926) reported that the rabbit testis was acutely damaged by cadmium; Cameron \& Foster (1963) described somewhat inconsistent changes; Smith, Smith \& McCall (1960), referring to experiments by Wells, Smith \& Kench (unpublished), as well as Kar \& Das (1962) reported that the rabbit testis was resistant to injury from subcutancously administered cadmium. Both Chiquoine (1964) and Erickson \& Pincus (1964) reported that the rooster testis was not damaged by cadmium, but conflicting reports have appeared concerning the effect of cadmium on the testis of the pigeon (Chiquoine, 1964) and dove (Maekawa, Suzuki \& Tsunenari, 1964). If strain differences in response to cadmium are also found in the female, this may explain why we have not noted the ovarian changes in prepuberal rats after treatment with $\mathbf{C d C l}_{2}$ described by Kar, Das \& Karkun (1959). An apparent discrepancy, which also might be due to differences in susceptibility of different substrains, appears in comparing Pařízek's (1964) observations that the administration of $\mathrm{CdCl}_{2}$ to pregnant rats between the 17th and 21 st day of gestation caused an interruption of pregnancy, with those of Maekawa \& Hosoyama (1965) who reported no abnormal changes when cadmium was administered to females on the 14th, 16th or 18th day of gestation.

This investigation was supported by grants CA-07004 and CA-6045 from the National Cancer Institute, National Institutes of Health, U.S. Public Health Service.

\section{REFERENGES}

Allanson, M. \& Deanesly, R. (1962) Observations on cadmium damage and repair in rat testes and the effects on the pituitary gonadotrophs. 7 . Endocrin. 24, 453.

Cameron, E. \& Foster, C. L. (1963) Observations on the histological effects of sub-lethal doses of cadmium chloride in the rabbit. 1. The effect on the testis. $\mathcal{J}$. Anat. 97, 269.

Ghiquorne, A. D. (1964) Observations on the early events of cadmium necrosis of the testis. Anat. Rec. 149, 23.

Erickson, A. E. \& Pincus, G. (1964) Insensitivity of fowl testes to cadmium. 7. Reprod. Fertil. 7, 379.

\footnotetext{
* Charles River Breeding Laboratories, Inc., North Wilmington, Massachusetts.

† Carworth Inc., New City, Rockland County, New York.

$\ddagger$ Hormone Assay Laboratories, Inc., Chicago, Illinois.
} 
Gunn, S. A., Gould, T. C. \& Anderson, W. A. D. (1961) Zinc protection against cadmium injury to rat testis. Arch. Path. 71, 274.

Gunn, S. A., Gould, T. C. \& Anderson, W. A. D. (1963) Cadmium-induced interstitial cell tumors in rats and mice and their prevention by zinc. 7. nat. Cancer Inst. 31, 745.

Hessel, G. (1926) Untersuchungen über das Schicksal des Cadmiums nach parenteraler Einverleibung. Biochem. Z. 177, 176.

KAR, A. B. \& DAs, R. P. (1960) Testicular changes in rats after treatment with cadmium chloride. Acta biol. med. germ. 5, 153.

KAR, A. B. \& DAs, R. P. (1962) Sterilization of males by intratesticular administration of cadmium chloride. Acta endocr. (Copenh.), 40, 321.

KAR, A. B., DAs, R. P. \& KARKUn, J. N. (1959) Ovarian changes in prepuberal rats after treatment with cadmium chloride. Acta biol. med. germ. 3, 372.

Kar, A. B., Dasgupta, P. R. \& Das, R. P. (1961) Effect of a low dose of cadmium chloride on the genital organs and fertility of male rats. F. scient. ind. Res. $20 \mathrm{C}, 322$.

Mafkawa, K. \& Hosoyama, Y. (1965) Morphological and functional sex-differentiation in rats born to cadmium-injected mothers. Zool. Mag., Tokyo, 74, 24.

Maekawa, K., Suzuki, T. \& Tsunenari, Y. (1964) Damage of the gonads induced by cadmium in male and female ring doves (Streptopelia risoria). Acta anat. nippon. 39, 294.

Mason, K. E., Brown, J. A., Young, J. O. \& Nesbit, R. R. (1964) Cadmium-induced injury of the rat testis. Anat. Rec. 149, 135.

Meex, E. S. (1959) Cellular changes induced by cadmium in mouse testis and liver. Brit. 7. exp. Path. $40,503$.

Paḱízek, J. (1957a) The destructive effect of cadmium ion on testicular tissue and its prevention by zinc. 7. Endocrin. 15, 56.

Pařízek, J. (1957b) Kastrace kadmium. (The castrating effect of cadmium). Statni zdravotnicke nakladatelstvi, Prague.

PAŘ́źzK, J. (1964) Vascular changes at sites of oestrogen biosynthesis produced by parenteral injection of cadmium salts: the destruction of placenta by cadmium salts. F. Reprod. Fertil. 7, 263.

PaŕízeK, J. \& Zahor, A. (1956) Effect of cadmium salts on testicular tissue. Nature, Lond. $177,1036$.

Smith, J. P., Smith, J. C. \& McCall, A. J. (1960) Chronic poisoning from cadmium fume. F. Path. Bact. 80, 287. 